Chapter 21

\title{
THE DEVONSHIRE CAVENDISHES: POLITICS AND PLACE
}

\author{
Sue Wiseman*
}

What CAN THE Chatsworth Cavendishes tell us about the literary and political culture of seventeenth-century England? As Mark Girouard puts it, the dynastic house and land were part of the "pursuit of pleasure and power" in a race to maintain position. That in the case of the Chatsworth Cavendishes the family's seventeenth-century history and later significance are bound together is shown in almost any item of modern Chatsworth marketing or souvenir. For example, many Chatsworth souvenirs take the form of tableware-and, like the serving bowl shown (Figure 21.1), how they present Chatsworth is suggestive with regard to past and present. This bowl shows us a view of William Talman's 1687-1688 remodelling of the house. Designed for fruit-serving, the bowl utilizes spooning depth to offer a close-up symmetrical view of the façade and a synoptic iconography of the house. It excerpts for the purchaser the key takeaway details of a Chatsworth visit, showing a seat of power: hill landscape in the distance shaped by the presence of the house, colonnaded façade, designed gardens, statuary, river. However, this peaceful scene of aristocratic dominance may be compared with another seventeenth-century vignette of Chatsworth from a distance that takes in the landscape around it. Published in English in the year Talman completed his remodelling but written earlier, a poem describes seeing Chatsworth in a different context:

\footnotetext{
Derwin appeares but as a crooked line,

And Chatsworth as a point it doth entwine.

W'had gone but little further, when we found

The Hills soft back, cut deep with many a wound.

And did the earth in whitish ranks espie

Cast up in heaps, upon the surface lye. ${ }^{1}$
}

So Thomas Hobbes interpreted the lead-mining geography in which Chatsworth sat, a geography the heritage dish has cleansed not only of mines but, notably, of the people who made it.

Given that power and connection are bound up together, the names of elite people and their places feature heavily in the following exploration of some of the sixteenthand seventeenth-century family dynamics. If Chatsworth the house has come to stand for the Devonshire dynasty, the family that owned it were often elsewhere in pursuit

\footnotetext{
* I am grateful to the editors and particularly Dr. Rutter for patience and comments.

I Thomas Hobbes, anonymous translation, De mirabilibus pecci being the wonders of the peak in Darby-shire, commonly called the Devil's Arse of Peak: in English and Latine (London, 1678), 18.
} 


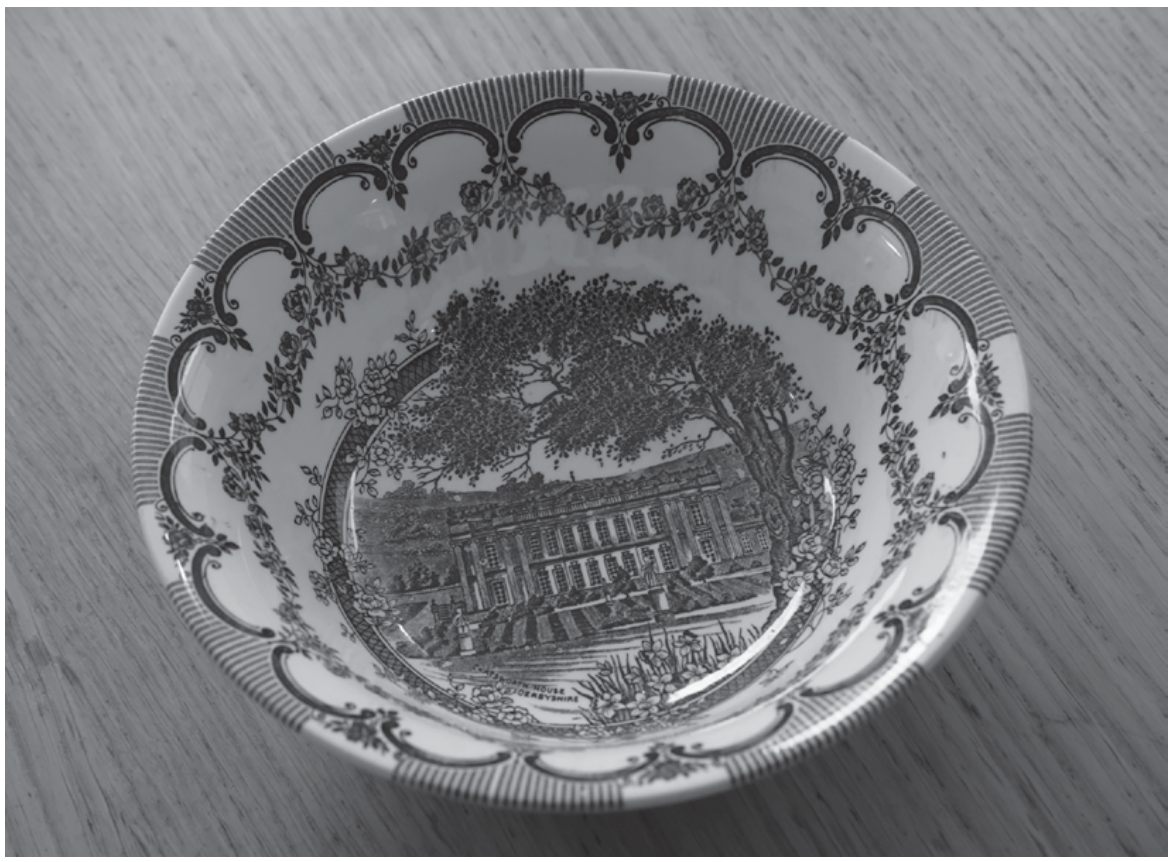

Figure 21.1. Brown and white tableware bowl with view of William Talman's 1687-1688 remodelling of Chatsworth House. Sue Wiseman.

of pleasure or power and were in London, at other houses, at the houses of relatives, or, in the case of the 2nd and 4th Earls, travelling. As Girouard notes, the family might be at Chatsworth for well under half the year. ${ }^{2}$ To better understand the early modern significance of the Devonshire Cavendish family, their situation in relation to the wider clan, their national pretensions, and their strong association with Chatsworth and with Derbyshire, what follows briefly explores the fortunes of just three of the family's seventeenth-century members. It focuses on William, the 2nd Earl of Devonshire; his long-lived widow, Christian (née Bruce); and their grandson, William Cavendish, the 4th Earl and 1st Duke.

\section{“Family Was Everything”: Sons, Daughters, Stepchildren}

The Chatsworth Cavendishes owe their existence to the rise of Elizabeth Hardwick of Hardwick, whose career bound together marital, political, and architectural power.

2 Mark Girouard, Life in the English Country House (Yale University Press: London, 1978), 6 and n6. See Peter D. Brown and Karl W. Schweizer, William Cavendish, Fourth Duke of Devonshire Memoranda on State of Affairs 1759-1762 (London: Royal Historical Society, 1982), 3. 
She clearly wanted that importance displayed in the county of her birth, Derbyshire, and the lands she acquired in that county give the locations of families interwoven with those of the Devonshire Cavendishes - the Newcastles, Pierreponts, and Talbots. Elizabeth Hardwick (married successively to the local Robert Barlow, treasurer William Cavendish, William St. Loe, and the Earl of Shrewsbury) had already begun building her version of Chatsworth when her second husband, William Cavendish, died in 1557. Her fourth (and final) husband, the 6th Earl of Shrewsbury, was an aristocrat. Just as she married him, in 1568, he was tasked, or cursed, with being gaoler for Mary, Queen of Scots. For all the problems the marriage was to bring, it also brought Bess of Hardwick into the aristocracy.

On the same day she attained aristocratic status, Elizabeth Hardwick sought to consolidate her place in it, for on that day her heir Henry married Shrewsbury's daughter Grace and her daughter Mary Cavendish married Gilbert Talbot, his son. In this move she tied her children fast to rank and privilege, but she also became mother-in-law to two of her stepchildren. Francis Bickley, the historian of the Cavendish family, thought that "family was everything" to Elizabeth Hardwick. Understanding family in its economic and dynastic sense, the countess seems to have consolidated land and capital with minimal attention to human relations or suffering. The plan worked in setting the personnel for a dynastic drama. Even though her marriage ended in acrimonious separation and her heir, Henry, died without legitimate children, the properties passed to her other two sons, William and Charles. These sons founded the twined dynasties of Newcastle and Devonshire. Charles Cavendish inherited Welbeck and set in train the Newcastle dynasty, discussed extensively elsewhere in this volume. William Cavendish, who inherited Chatsworth and Hardwick, became Baron Cavendish of Hardwick in 1605 and purchased the title of Earl of Devonshire in 1618. ${ }^{3}$ The Devonshire Cavendishes, then, were densely allied to other Cavendishes, but through the marriages they were also more distantly allied to many families in the area. Thus Elizabeth Hardwick's stepson and son-in-law, Gilbert Talbot, became the 7th Earl of Shrewsbury, and the Shrewsbury daughters allied the Devonshire Cavendishes to the Saviles of Rufford and beyond. It is in this context, tightly bound through layered marriages but also in relations of rivalry, that the Chatsworth Cavendishes emerge.

The Countess of Shrewsbury died in 1608, leaving Chatsworth to her eldest son, Henry. Henry sold the house to his brother William, and in 1616, when Henry died, William Cavendish, Lord Cavendish of Hardwick, who possessed Oldcotes, Hardwick, and Chatsworth, became an important landowner. In 1608 he had married his son, William Cavendish, to Christian Bruce, and in the same year he engaged his son's near contemporary, the freshly graduated 20-year-old Thomas Hobbes, as his tutor. The period between Hobbes's arrival in the Cavendish-Devonshire household and his charge's early death in 1628 sees the household marked by engagement also with Ben Jonson and some other writers. The period seems to indicate some literary patronage and pretensions on

3 Francis Bickley, The Cavendish Family (London: Constable, 1911), 33. 
William's part and so serves as a foil illuminating by contrast the achievements and aesthetic and philosophical investments of the Newcastle households.

For all that Hobbes is rightly seen as at the hub of intellectual circles including Charles Cavendish of Welbeck and the Earl, later Duke, of Newcastle, the philosopher was also an important presence in the Chatsworth household. He seems to have been significant not only in the intellectual and potentially political thinking of the 2nd Earl of Devonshire, and probably in that of his son and that of the Williamite 1st Duke too, but if we focus on the Chatsworth Cavendishes, we see that he was also a participant in the household's aesthetic sociability. Indeed, it seems that Hobbes described his twenty years' service with the 2nd Earl of Devonshire as "by far the most agreeable period of my life," noting that William "was not only a master, but a friend as well." ${ }^{4}$ The pair set out on a tour that included Venice, Rome, and Naples, and Hobbes's biographer finds the years 1615-1620 obscure in Hobbes's life, beyond rumour that the young 2nd Earl used to send Hobbes to borrow money for him. ${ }^{5}$ Hobbes was a close companion and servant.

While for many years it has been assumed that the young Sir William Cavendish married and then immediately went on a European tour with his new tutor, in fact records may suggest a more complex trajectory and perhaps less time abroad than we have assumed. Hobbes's biographer finds the young Cavendish in London in the 1610s and as a member of the addled Parliament of $1614 .{ }^{6}$ After the death of Prince Henry in 1612, William Cavendish seems to have had considerable contact with the new Prince Charles, both as an earl's son on ceremonial occasions and when the king and prince were on progress in the north. Thus James I was at Derby and in Nottinghamshire in 1609 and William participated in the games associated with the installation of the Prince of Wales in 1616, was among the mourners at Queen Anne's funeral in May 1619, may well have been present when James I visited Welbeck in 1619, and was almost certainly present when he visited Hardwick in the same year. ${ }^{7}$ Thus Sir William Cavendish, as he was styled, had many contacts with the royal family and particularly James and Charles.

In the later part of the 1610s, Sir William Cavendish took up the place in ceremonial life designated for earls' sons and began to associate socially with the court. At this point, texts associated with the Cavendish-Devonshire household start to emerge. One such text is a christening entertainment by Ben Jonson. ${ }^{8}$ The text itself is short and the occasion or occasions of its performance enigmatic. The text itself has three central female antimasque roles and they are the female staff of a lying-in chamber-Holdback the midwife, Dugs the wet nurse, and Kecks the dry nurse. The entertainment uses a fight

4 "Vita Carmina Expressa," quoted in A. P. Martinich, Hobbes: A Biography (Cambridge: Cambridge University Press, 1999), 19.

5 See Martinich, Hobbes, 28.

6 Martinich, Hobbes, 29-30.

7 John Nichols, Progresses of King James I, 4 vols. (London, 1828), 3:27.

8 Ben Jonson, A Cavendish Christening Entertainment, ed. James Knowles, The Cambridge Edition of the Works of Ben Jonson, gen. ed. David Bevington, Martin Butler, and Ian Donaldson, 7 vols. (Cambridge: Cambridge University Press, 2012), vol. 5. 
for primacy among these three to make an entertainment that moves with the guests as they come in, drawn in by a "Forester," and is still continuing as they leave, adjudicated in the meantime by the figure of the Mathematician. ${ }^{9}$ The script of the brawl concerns the honour and decorum of the nurse's calling worked through in terms of wet and dry vices. It opens with Holdback, the midwife, demonstrating the boy to the gossips:

holdb aCk. Now God multiply Your Highness and my honorable lord, too, and my good lady, the countess! I have one word for you all, "Welcome!"-which is enough to the wise and as good as a hundred, you know. This is my day! My lords, and my lady, how like you my boy? Is't not a goodly boy? I said his name would be Charles when I looked upon Charles's Wain t'other night, he's born under that star. I ha' given measure, i'faith. He'll prove a pricker, an God will, by one privy mark that I found about him. Would you had such another, my lord gossips, every one of you, and as like the father! Oh, what a glad woman, and a proud, should I be to be seen at home with you upon the same occasion!

(lines 19-28)

Celebrating the baby at the same time as offering her professional service, Holdback gives us some identifications related to the guests. She welcomes Prince Charles, who is to stand godparent, and an unnamed countess and, elsewhere, she refers to "my Lord Chancery," taken by the recent editor to be Lord Chancellor. ${ }^{10}$ Thus, if the identification of Chancery as a malapropism for Chancellor is accurate, as the evening begins, the entertainment establishes a sharp contrast between employees and guests. On the one hand are the countess, Prince Charles, and, it seems, the Lord Chancellor. The Lord Chancellor seems to be very likely to have been Francis Bacon, Lord Chancellor 1618-1621, who was indeed a contact of the Devonshire William Cavendish. ${ }^{11}$ Counterposed to court and government are the farcical female characters, presumably men of contrasting size comically cross-dressed, playing the raucous and corrupt female servants as a grotesque foil to the finest in the land.

The rolling fight gradually moves around the house, culminating in violent accusations:

keCks. Indeed, you had like to have overlaid it the other night and prevented its christendom, if I had not looked unto you, when you came so bedewed out of the wine cellar and so watered your couch that, to save your credit with my

9 There are a few candidates, and Hobbes is possible. On Hobbes's later acknowledgement as a mathematician, see Katherine Dunlop, "Hobbes's Mathematical Thought," in The Oxford Handbook of Hobbes, ed. A. P. Martinich (Oxford: Oxford University Press, 2016), 76-105.

10 Jonson, Christening Entertainment, 1:39 and note.

I I On the possible acquaintance of William Cavendish and Bacon by late 1615, see Martinich, Hobbes, 28-29; on later contact, see 38-41, 53-54, 65-66. 
lady next morning, you were glad to lay it upon your innocent bedfellow, and slander him to his mother how plentifully he had sucked. This was none o'your dry jests now, this was a soaker.

holdb aCk. Ay, by faith, was't. An you overflow so, it's even time to stop the breach and pack you both hence. Get you in! Here comes a wise man will tell us another tale.

(lines 159-66)

The "wise man" is a "Mathematician," who prophesies the greatness of the child. Kecks is accusing Dugs, the wet nurse, of being so sodden drunk that she almost "overlaid" the baby, a hazard of sleeping with infants where the infant is suffocated or killed by an adult sleeper. Such accidents were but a step from infanticide, both in execution and accusation, and in the early modern imagination the two went together, so though the accusation mellows to become a mere incident of drunken bedwetting, we can see clearly a purposive directness in the fashioning of farce from the very darkest fears of post-partum disaster, focalized for an audience, some of whom were in the midst of such an experience, through the staging of servants-and the midwife, which was the only certificated occupation open to women-as grasping, lying, malicious scroungers and sots.

In its current form, the entertainment seems like a text made of a compound of others and which suffers from gaps and uncertainties which include who it was performed for (or first performed for) and when and where it might have been staged. The text's most recent editor, James Knowles, sees the "Christening Entertainment" as more likely to have been produced by the Newcastle household. However, possibly encouraged by the inauguration of Charles as the new Prince of Wales in 1616, the Cavendishes had a crop of Charleses, with at least one each to the Devonshire and Chatsworth branches. The entertainment is found in MS Harleian 4955, a scribal text that in the section it is in records a number of texts that seem to address both the Newcastle and Devonshire families. Indeed, some material in the early part of this manuscript addresses all the children of the Hardwick-Shrewsbury alliance, such as the celebratory poem by Francis Andrews enumerating the family's houses, ending with Rufford, a Savile house via the daughter of the 6th Earl of Shrewsbury:

Worsope a duke, Hardwicke an Earle,
Welbeck a Vicount, Bolser a Pearle
The rest are Jewells of the Sheeres
Bolser the pendant of the Eare
Yet an old Abbey hard by the way
Rufford giveth Almes more than they. ${ }^{12}$

So the book's contents for this period suggests that in the 1610 s and 1620 s patronage might be a little more fluid among multiple households than the later dominance of the Newcastles suggests, and the entertainment may well sit in such a space.

12 London, British Library, MS Harley 4955, fol. 67v. 
However, in the text itself is a line of puns which may associate the text with the Chatsworth branch:

Holdback. ... Nurse, ha' done, let the music ha' their play. You have made a joyful house here, i'faith! The glad lady within i'th' straw I hope has thanked you for her little carl, the little Christian.

(lines 40-42)

If a carl is a small churl and a small Charles (the baby is these), it is also, after baptism, a little Christian. At the same time, however, the use of the term might also suggest that the entertainment was at least at some point performed for the Devonshire Cavendishes, as it also implies that the baby might be a small version of Christian, William's wife andpossibly - the baby's mother. According to James Knowles, the Chatsworth (Devonshire) Charles was born in $1619 .{ }^{13}$ It is likely, then, that some or all of this material was used by the Devonshire family and possible that at some point in 1619, marked in London by other princely godparentings, either in London or in Hardwick, Ben Jonson's christening entertainment was staged by the Devonshire Cavendishes. ${ }^{14}$

Other textual productions include the anonymous publication of essays by Hobbes's pupil, Horae Subseciuae Observations and Discoveries (1620). Among the essays the earl writes is one evaluating a country life, "so farre as it hath relation to men of great qualitie, and estates." ${ }^{15}$ Besides traditional praise for being "away from the presse, business, and imployment" of court and city, there is a focus on country life's "disaduantageous inconueniences," particularly that it "secludes us from a knowledge of the Court, and government there, and also eclipseth from our acquaintance, the Great men, and guiders of the State." ${ }^{16}$ Young William Cavendish's engagement with the essay form might suggest Bacon and others, but it might also be more narrowly focused as a rite of passage to adulthood completed on return from his European tour and as he embarked on family life.

While the 2nd Earl's aesthetic achievements are small in comparison to those of the Newcastle family, those are mainly found later and, of course, William died just two years after inheriting his title-in 1628. He was said to have feasted himself to death, and certainly he left his estate in dire jeopardy. As well as being contrasted with the Newcastle brothers William and Charles, the Devonshires can also be compared with three women of the same generation-the Talbot sisters and Christian Cavendish herself. As we recall, the Earl of Shrewsbury's son, Gilbert Talbot, had been married to Shrewsbury's daughter, Mary. Talbot, Mary Stuart's gaoler, spent his life in furious and widely reported

13 Knowles writes, "The Cavendish-Devonshire case centres on Charles Cavendish, second son of 'Lord Cavendish and Christian his lady', who was baptized on 15 June 1619, not 1620 (London Guildhall, MS 4508/1)."

14 Nichols, Progresses, 554.

15 Horae Subseciuae Observations and Discoveries (London, 1620), 135.

16 Horae, 138, 161, 163. 
litigation but left three notable daughters. The most obscure is Mary Talbot, who in 1604 married the Earl of Pembroke, who became Mary Wroth's lover, and the best-known, Aletheia, married the Earl of Arundel and was a patron and collector. As significant is a third daughter, Elizabeth Talbot (1582-1651), who married Henry Grey, heir to the Earl of Kent, and lived at Wrest. She was probably the pupil of Sir John Florio and was the dedicatee of his translation of Montaigne's essays. Her connections included Sir Robert Cotton and John Selden, with whom she lived at her London house after her husband died in 1639, and at least one publication, A choice manual of rare and select secrets in physic and chyrugery (1653), is associated with her and seems to draw on her recipes.

The wife of William Cavendish from 1608, Christian Cavendish, was effective politically and in estate management; she was also tenacious and long-lived. When she was widowed in 1628, Christian Cavendish inherited an estate that was almost bankrupt. The 2nd Earl had become so indebted that he had just persuaded Parliament to pass an act allowing him to sell his entailed lands. Under Christian Cavendish, the estates remained in the family and she was strikingly successful in remaking the fortunes he had so dissipated, restoring reputation and fortune together to regain a prime place in the county and country for her son, the 3rd Earl. So astute was Christian in pursuit of her ends that Charles I is said to have commented on her control of his judiciary. ${ }^{17}$

Three incidents are illuminating with regard to Christian Cavendish: the marriage negotiations with her recorded by the Countess of Leicester in her letters to her husband, her Royalist activity during the English Civil War, and her possible (at present partially) excavated relationships with writers including the Earl of Pembroke and Edmund Waller. However, that this powerful and well-connected figure might well repay sustained investigation is suggested by the texts readily available. Three examples give a sense of her influence.

On April 13, 1637 the Countess of Leicester wrote to the Earl of Leicester,

Ho[lland] received an answear from my lady De[vonshire] to his proposition, wich he showed me. It was full of sivilitie, craft and coldness. I am confident she meanes little of what she saide, and yeet I believe shee is understood. Shee speaks much of the libertie shee gives her sone, and yeet every on persceavs that he dares not eat or drinke but as she appoints. Nothing can be more manifest then that shee has advertions to us, upon what reasons I do not know. Your sivilities to my lord of De[vonshire] are not much considered, for I never heard a word of acknowledgement. ${ }^{18}$

This is the first letter in a sequence referring to the Leicesters' courting of the future 3rd Earl of Devonshire-William Cavendish—as a match for their daughter. This letter's evaluation of the situation may be accurate, for no match ensued. However, as the elaborate manoeuvres take place, the countess discloses her view of the future 3rd Earl as almost wholly lacking in agency. She writes that "my lady De[vonshire]" speaks "much

17 For this widely retold story see, e.g., Martinich, Hobbes, 86.

18 G. Dyfnallt Owen, Report on the Manuscripts of the Right Honourable Viscount De L'Isle, V. C., Preserved at Penshurst Place, Kent, "The Countess of Leicester to the Earl of Leicester," April 13, 1637, HMC 77:101. 
of the libertie she gives her sone, and yeet every on perceavs that he dares not eat or drinke but as she apoints." ${ }^{\prime 19}$ The image of Christian Cavendish as controlling and cold may not be accurate but, certainly, she was an able and astute operator in personal and political matters.

It is clear that the Countess of Devonshire was motivated by politics. Her biographer tells us that she was deeply involved in Royalist plotting in the 1650s, and evidence survives of her attempts to broker the Duke of Lauderdale's release. During the civil wars Lauderdale had presented himself as a broker and had paid the penalty. Exiled in 1648 to The Hague, he then came back with Charles Stuart (later Charles II) to the battle of Worcester, where the Royalists were routed and he was among the prisoners. ${ }^{20}$ Cavendish writes to him in 1658 that "it was in dispute amongst your friends how your business should bee laid" and sets out her own position with regard to conflicting plans. Some thought that his freedom should be taken to Parliament, "which they knew immediately would give you your liberty," but she was concerned to keep the Protector involved:

I confess I was in no means willing that should be done in regard I knew you had some enimyes now sitting there that when it came to the debate of your estate, would have put a spoke in your wheele besides it would have been a way would very much have disobliged my Lord Protector who already hath made so large a promis in your Lordships particular that truly I am very confident he will show your L[ordship] as much favour as possibly he can, within this 3 dayes I received a message from the Lieutenant General that the business should be done a and to my likeing. ${ }^{21}$

In fact, attempts to free Lauderdale, such as the one Christian Cavendish is here promoting, came to nothing and he was in prison until 1660. However, the countess's deep involvement in Royalist plotting, her influence, and her many connections are apparent here, even if in this case it turned out she was claiming more influence than she had. Her biographer records troops dispatched to fetch her from her brother-in-law's house at Ampthill to forestall her activities. ${ }^{22}$ That Christian Cavendish was in communication with Lauderdale, however, may suggest something about her religious as well as her political persuasion.

In her later years Christian Cavendish seems to have welcomed a range of writers at her house at Roehampton. In 1661 the dedication by one apparently tasked with oversight of the printing process described the Earl of Pembroke's poems as a "Monument that your Ladiship hath erected to his memory, will outlast the calculation of all Astrologers." She has facilitated publication when:

19 Countess of Leicester to the Earl of Leicester, April 13, 1637.

20 Ronald Hutton, "Maitland, John, Duke of Lauderdale (1616-1682), Politician," in Oxford Dictionary of National Biography (May 25, 2006).

2I Christian Cavendish to Earl of Lauderdale, April 5, 1658, London, British Library, MS Additional 38,855, fol. 87.

22 Thomas Pomfret, The Life of the Right Honourable and Religious Lady Christian Late Countess Dowager of Devonshire (London?: 1685), 79. 
all the Muses seemed to be fled, and to have left nothing behind them, but a few lame Iambicks, canting at the corners of our desolate streets; yet they are now content to be awakened by your Ladiships command, \& under your Patronage to come abroad, and meet, and salute the peace that gave them their first being. ${ }^{23}$

Christian here is acclaimed as one of the first to return to publishing after the Restoration, helping to bring a truly poetic culture back to life. She appears to have been a patron of Sir Edmund Waller and was probably the recipient of more verses than we are currently aware of. While her son, William Cavendish, the 3rd Earl, lived a retired life, his mother did not, and her household at Richmond was clearly a centre for cultural royalism and patronage.

Politics and building were the lifelong preoccupations of Christian Cavendish's grandson, William Cavendish, the 4 th Earl and later the 1 st Duke. ${ }^{24}$ William seems to have been recognized as promising at an early age. In 1648 Hobbes recommended a curriculum for him, and in the late 1650s, when his grandmother was plotting in London, he spent time in Paris and Florence. After the Civil War, at the Restoration, he was once again apparently close to the court, being chosen to serve Charles II at his coronation in 1660. In the same year he was married to Mary Butler, the daughter of the 1st Duke of Ormond, though, as was much noted at his death, he was a multiple adulterer and had a long-term mistress from the London stage-Mrs. Heneage. ${ }^{25}$

In June 1688, four years after he acceded to his lands and houses, the 4th Earl received a carpenter's bill for "takeing downe the partitition att the end of the hall \& wainscoate takeing down in the hall \& boards taking up there and shoreing in the hall and in the Leicester Apartment, and in the white roome over the hall." ${ }^{26}$ The same summer saw him inviting William of Orange to intervene in England's affairs under the Roman Catholic James II. Both events were to shape the role of the Chatsworth Cavendishes in the later years of the seventeenth century. The carpenter's bill is for early work on the reshaping of Chatsworth to become, broadly, the house we know today, though it seems that the earl initially planned only some alterations to the Elizabethan house. ${ }^{27}$ On November 17 of the same year, many of the workmen employed on William's steadily enlarging rebuilding project were with him and other troops at Derby.

The duke's appearance at Derby with a troop of horse followed a long trajectory of increasing political discontent and alliance with the country party. When James II

23 John Donne, "To the Right Honourable Christiania, Countess of Devonshire, Dowager," in Poems Written by the Right Honourable Earl of Pembroke (London, 1660), sigs. A1v-A2r. The relationship marked here must be with John Donne the younger.

24 David Hosford, "Cavendish, William, first duke of Devonshire (1641-1707), politician," in Oxford Dictionary of National Biography (October 4, 2008).

25 See Hosford, "Cavendish, William."

26 Building accounts, Chatsworth, quoted in Francis Thompson, A History of Chatsworth (London: Country Life, 1949), 46. Quotation modernized.

27 John Barnatt and Tom Williamson, Chatsworth: A Landscape History (Macclesfield: Windgather, 2005), 52-53; see also Thompson, History of Chatsworth. 
acceded to the throne, Cavendish was one of the seven signatories of the invitation sent to William of Orange, and it was his responsibility to raise troops in Nottingham at the prince's landfall. When others joined him and the numbers grew, confusion and competition ensued. Remaining in Nottingham in some confusion, they all set off through the Midlands towns to Oxford, arriving on December 15 and going from there to continued frantic activity in Parliament, where he was instrumental in the safe arrival of William and Mary. In 1689 he became a member of the Privy Council and for the rest of his life was a recipient of what David Hosford calls the "trappings of power and position." 28

The duke, as he was from 1694, did not pursue a political career with energy, and, as a consequence, the 1688 muster was his political apogee. He owes his fame to his magnificent house, Chatsworth, and to his lifelong passion for building and altering each wing in turn until, as the engraving in Jan Kip and Leonard Knyff shows us, he had made an extraordinary mansion. Key to this project was William Talman, the architect. Talman was not a famous architect when he began work on Chatsworth. There has been a longstanding assumption that he worked on Thoresby Hall, home of Henry Pierrepont, Earl of Kingston-upon-Hull and later Marquess of Dorchester, who was related to the Chatsworth Cavendishes through Elizabeth Hardwick's second husband, William Cavendish. However, this assumption has recently been revised, and Peter Smith suggests that although there is no doubt of Talman's dominance as an architect of the country houses of the later seventeenth century, and his involvement in over thirty, he came to Chatsworth after an initial record of developing plainer houses. ${ }^{29}$ The 4 th Earl, contrastingly, came to the rethinking from an education by Hobbes and an immersion in Italian culture. That Peter Smith describes Talman as "eclectic" may suggest that we should see the duke's hand as the main shaper of Chatsworth. However, rather than debate the honours in the shaping of Chatsworth, we can see a significant relationship of patronage and collaboration partly recorded in the changing practices and plans and partly visible only in the creation of a structure that speaks an English, and arguably Protestant, baroque. At the same time, we must recognize the local power of the pleasure gardens remodelled very significantly in a three-way collaboration between George London, Talman, and the earl. So, while we can speculate that the 4th Earl set out to return the Devonshire Cavendishes to national political importance and remodelled the south wing of Chatsworth in the service of that, in the event, the roles were in part reversed, with the rewards of one significant political year facilitating his buildings. However, that this is the case may suggest not that the 4th Earl had, in fact, no political ambitions but that he was expressing a politics of building that was allied also with the innovative retreats of the Civil War. Funded by monarchical reward and marked by increasingly close involvement with its daily management, the 1st Duke's Chatsworth arguably expresses an integrative concept of service with national politics.

28 Hosford, "Cavendish, William."

29 Peter Smith, "Talman, William (bap. 1650, d. 1719), Architect and Collector," in Oxford Dictionary of National Biography. 
The Kip and Knyff engraving of Chatsworth offers one ideological summary of how the Devonshire Cavendishes shaped the landscape of local and national politics through aesthetics, connections, and place. Between the Kip and Knyff engraving and the souvenir bowl with which we opened, a long and complex story unfolds, with the house at time of writing still in the hands of the Devonshires and hard at work building aristocratic power and pleasure in the Peak. However, we also opened with a different perspective on Chatsworth offered by Thomas Hobbes, and it is, after all, perhaps Thomas Hobbes who is the most significant figure in this story. As tutor and secretary, Hobbes binds together three generations of Devonshire Williams, and for all his powerful associations elsewhere, he spent much of his life sharing space with the people discussed here. While it is not possible to directly quantify his shaping influence, as Noel Malcolm tells us, Hobbes's letters track his intellectual connections when he is apart from them, but the Welbeck and Chatsworth Cavendishes were very often in London, and the absence of letters may speak of closeness as much as the surviving manuscripts. ${ }^{30}$ To Hobbes's overlapping connections with Charles Cavendish of Welbeck, Marin Mersenne, Robert Hooke, and others we must add the fact that he was for much of his life with the Devonshire Cavendishes.

For Hobbes's favourite, William Cavendish, the "disaduantageous inconueniences" of aristocratic country life meant being out of the swim of politics. Ill with palsy, in his later years Hobbes described to a friend his life at Chatsworth and Hardwick as causing a "want of learned conversation," which was "a very great inconvenience." 31 The Devonshire Chatsworths were hardly an intellectual centre, yet they kept Hobbes's letters and kept him long into his old age. At the same time, it is Hobbes who illuminates the resemblances and distinctions between the two branches of Bess of Hardwick's family, the Devonshire and the Newcastle lines; if the Devonshires supplied him with a livelihood and he tutored their sons, then the Newcastles seem also to have been strongly connected to him in the world of arts, sciences, and thought that they claimed and shared the European connections that came through these interests. These features differentiate them, in the main, from the Devonshire branch and perhaps exemplify the world that Hobbes missed at Chatsworth.

Neither the Devonshires nor the Newcastles seem to have responded as did Hobbes to the implications of the Derbyshire landscape and to Chatsworth as situated in a wider culture of work and hardship. He describes Chatsworth (in fact, the earlier Chatsworth, though his poem was translated as the new one came into view) as the first wonder of the Peak:

On th' English Alps, where Darbies Peak doth rise,

High up in Hills, that Emulate the Skies,

And largely Waters all the Vales below,

30 Noel Malcolm, "General Introduction," The Correspondence of Thomas Hobbes, 2 vols. (Oxford: Oxford University Press, 1994), 1:xxii.

3I John Aubrey, Brief Lives, ed. A. Clark, 2 vols. (Oxford: Oxford University Press, 1989), 1:338, quoted in Malcolm, "General Introduction," xxx. 
With Rivers that still plentifully Flow,

Doth Chatsworth by swift Derwins Channel stand,

Fam'd for it's Pile, and Lord, for both are grand.

However, he knows that lead is "the dark Prince of wealth" that defines the labour of those around the country house who, "if poverty compel," dig "To rob th' Exchecquer, of the Prince of Hell," and often in doing so are crushed by collapsing mines. According to the poem, those on the tour actually witnessed the aftermath of a mining accident. Two men have died and "Before our feet, a Corps digg'd up we see," while:

T'other lies buried in the earth, but still Hopes an extraction when 'tis Heavens will.

Upon the earth that from the mine was thrown,

A lazy people drawn from e'ry Town,

To see the mournful spectacle came down.

Two women weeping in the croud we spi'd;

One for the loss of joyes that she had tri'd,

T'other for want of hopes are now denied..$^{32}$

For all that the tone of the translation is almost comic, Hobbes is deeply aware of the world beyond the Chatsworth gardens.

\section{Bibliography}

\section{Manuscripts}

London, British Library, MS Additional, 38,855.

London, British Library, MS Harley, 4955.

\section{Other Works}

Aubrey, John. Brief Lives. Edited by A. Clark. 2 vols. Oxford: Oxford University Press, 1989. Barnatt, John, and Tom Williamson. Chatsworth: A Landscape History. Macclesfield: Windgather, 2005.

Bickley, Francis. The Cavendish Family. London: Constable, 1911.

Brown, Peter D., and Karl W. Schweizer, William Cavendish, Fourth Duke of Devonshire, Memoranda on State of Affairs 1759-1762. London: Royal Historical Society, 1982.

Donne, John. "To the Right Honourable Christiania, Countess of Devonshire, Dowager." In Poems Written by the Right Honourable Earl of Pembroke, sigs. A1v-A2r. London, 1660.

Dunlop, Katherine. "Hobbes's Mathematical Thought." In The Oxford Handbook of Hobbes, edited by A. P. Martinich, 76-105. Oxford: Oxford University Press, 2016.

Girouard, Mark. Life in the English Country House. London: Yale University Press, 1978.

Hobbes, Thomas. De mirabilibus pecci being the wonders of the peak in Darby-shire, commonly called the Devil's Arse of Peak: in English and Latine. Anonymous translation. London, 1678.

32 Hobbes, De mirabilibus pecci, 24. 
Horae Subseciuae Observations and Discoveries. London, 1620.

Hosford, David. "Cavendish, William, 1st Duke of Devonshire (1641-1707), Politician." In Oxford Dictionary of National Biography.

Hutton, Ronald. "Maitland, John, Duke of Lauderdale (1616-1682), Politician." In Oxford Dictionary of National Biography.

Jonson, Ben. The Cambridge Edition of the Works of Ben Jonson. General editors David Bevington, Martin Butler, and Ian Donaldson. 7 vols. Cambridge: Cambridge University Press, 2012.

Malcolm, Noel. The Correspondence of Thomas Hobbes, 2 vols. Oxford: Oxford University Press, 1994.

Martinich, A. P. Hobbes: A Biography. Cambridge: Cambridge University Press, 1999.

Nichols, John. Progresses of King James I. 4 vols. London, 1828.

Owen, G. Dyfnallt. Report on the Manuscripts of the Right Honourable Viscount De L'Isle,

V. C., Preserved at Penshurst Place, Kent. Vol. 6. Sidney Papers, 1626-1698. Historical Manuscripts Commission, 77. London: H. M. Stationery Office, 1966.

Poems Written by the Right Honourable Earl of Pembroke. London, 1660.

Pomfret, Thomas. The Life of the Right Honourable and Religious Lady Christian Late Countess Dowager of Devonshire. London?, 1685.

Smith, Peter. "Talman, William (bap. 1650, d. 1719), Architect and Collector." In Oxford Dictionary of National Biography.

Thompson, Francis. A History of Chatsworth. London: Country Life, 1949.

Sue Wiseman is Professor of Seventeenth-Century Literature at Birkbeck University of London. Her publications include Aphra Behn (Northcote House, 1996), Drama and Politics in the English Civil War (Cambridge University Press, 1998), Conspiracy and Virtue: Women, Writing, and Politics in Seventeenth-Century England (Oxford University Press, 2006), and Writing Metamorphosis in the English Renaissance 1550-1700 (Cambridge University Press, 2014). 